\section{Effect of the Muscle Energy Technique and Self-Stretching on Flexibility Gain of Posterior Chain}

\title{
Abstract
}

Introduction: Flexibility is called as smooth moving, painless and without restriction of a joint The reduced flexibility will result in decreased performance and incoordination of movements. To prevent such damages, there are adequate treatments based on stretching that will improve the functionality of the subject.

Goal: To evaluate the effectiveness of the muscle energy technique (MET) and the self-stretching on flexibility of the posterior chain.

Method: Experimental study, quantitative, performed with 26 students of the undergraduate Physiotherapy of Faculdades Integradas de Patos, which were divided into 2 groups, G1, submitted to the technique of muscular energy, and G2, submitted to self-stretching, with a total of 13 participants in each group. The flexibility of the posterior chain was evaluated by the sit-and-reach test, using the test bank Wells. The data analysis was made using the computer program SPSS version 18.0, through descriptive and inferential statistics.

Results: Most of the subjects were female. In G1, the mean age was 20.0 years and in $G 2,20.3$ years. The subjects of $G 1$, before the attendances, presented average flexibility of $20.42 \mathrm{~cm}$ e and after, $33.69 \mathrm{~cm}$, while the subjects of $\mathrm{G} 2$ presented 20.38 and $32.73 \mathrm{~cm}$, before and after the attendances, respectively.

Conclusion: MET and the self-stretching showed to be efficient for flexibility gain of the posterior master chain in the studied sample, however the flexibility gain obtained after MET was higher than that obtained after self-stretching.

Israel de Lucena Marques', Maercio Mota de Souza², Thiago Alves Munguba², Elvis Costa Crispiniano², Felipe Longo Corrêia de Araújo²,

Sêmio Wendell Martins de Melo,

Elicarlos Marques Nunes ${ }^{3}$, Tarsila Fernandes Vidal ${ }^{4}$

1 Physiotherapist from Faculdades Integradas of Patos, Patos (PB), Brasil.

2 Physiotherapists Department of Physiotherapy from Faculdades Integradas de Patos, Patos (PB), Brazil.

3 Nurse. Master in public health. teacher Nursing Department from Faculdades Integradas de Patos, Patos (PB), Brazil.

4 Under graduation Student in Physiotherapy at Faculdades Integradas de Patos, Patos (PB), Brazil.

\section{Contact information:}

Elicarlos Marques Nunes.

Address: Horácio Nóbrega, S/n, Belo Horizonte, Patos, Paraíba, Brazil. CEP: 58.704-000.

¡ elicarlosnunes@yahoo.com.br

Keywords

Stretching; Flexibility; Muscle Energy Technique. 


\section{Introduction}

The smooth movement, painless and without restriction of a joint a series of them represents the degree of flexibility. This depends on the extensibility of muscle tendinous units, transposing a joint [1]. Flexibility is the quality of what is flexible, that can bow or bend, which has elasticity, which is malleable, has dexterity or agility, but also what is tamable, complacent, submissive, smooth [2].

Most of the activities of daily life requires a minimum of flexibility from normal individuals. The reduced flexibility entails a series of limitations, ranging from a performance decrease in implementing trivial tasks, such as sitting or dressing up, until the lack of coordination in movements. Just like the flexibility is essential for the normal movement, its maintenance is important to prevent injuries in musculoskeletal- tendinous unit [3].

Training courses that are geared to the improvement/maintenance of flexibility with planned exercises, they have a role to lengthen ligaments, capsules and also increase the extensibility of the muscle tendinous units, also increasing the joint movement amplitude [4].

There are some simple methods to lengthen the non-contractile or contractile components of the muscle tendinous unit, such as the active stretching, passive stretching applied manually, the active inhibition and self-stretching. Other stretching methods can also be used as the ballistic stretching, static stretching and also the stretching techniques by neuromuscular proprioceptive facilitation [1].

Stretching is the term used to describe the physical exercises that increase the length of the structures of soft tissues and, as a consequence, the flexibility [5]. The use of stretching to increase flexibility has as a basis, usually, the idea that it can decrease the incidence, the intensity or duration of the tendinous muscle lesion and of the joints [6].

To be carried out in the correct way, the stretching must be performed in a sustained position until the subject stretched feels a slight feeling of traction in the muscle, during the stretching maintenance. However, if during the stretching there is the sensation of pain, paresthesia, dizziness, or some other harmful symptoms, exercise should be interrupted immediately [7].

Other stretching methods such as the muscle energy techniques (MET) constitute osteopathic procedures that have the function to lengthen fascias, muscles and also joints [1].

MET is based on the fact that soon after a prestretching contraction of a determined muscle retracted, this muscle will relax as a result of autogenic inhibition and it will be more easily stretched (8). The previous contraction to the stretching also leads to a reflex relaxation, followed by a decrease in the electromyography activity in the retracted muscle [9].

MET uses principles of the neurophysiology with manual stretching techniques to lengthen shortened muscles and relax super active muscles [3]. In the performing of the technique the subject is instructed to contract isometrically the agonist muscle in 20 to $25 \%$ of its available workforce. After the period of isometric contraction, the therapist uses actively a contrary force to lengthen the muscle that has previously contracted, in order to obtain amplitude gain [10].

In the procedure for the MET application the therapist offers sufficient resistance, compared with the force exerted on the isometric contraction of the patient. The contraction should be maintained for 10 seconds, which is the time required for the tendinous body of Golgi be excited, and the muscular spindle be inhibited, and this way the muscle can be led to a new range of movement [3].

In muscles, there may be shortenings due to contractures generated by traumas or even lack of force or flexibility, which later will generate the muscle imbalance and cause poor postures [11].

The muscles of the posterior chain are tonic muscles responsible for maintenance of the orthostatic position against the gravitational action. For this 
reason, they are known as antigravity muscles. The master posterior chain is composed of the muscles that compose the sole of the foot, triceps surae, hamstrings, pelvitrocanterians and spinal erectors [12].

Considering the aforementioned, it is the objective of the present study to evaluate the efficacy of muscle energy technique and the effectiveness of the self-stretching on flexibility gain of the master posterior chain.

\section{Method}

\section{Type of study}

It was an experimental study, i.e., an experiment in which the individuals were placed into groups in order to have the effects evaluated under controlled conditions by observation [13]. The study was quantitative, once that it sought to quantify factors, search for statistical correlations and probabilistic and, when possible, generalize them [14].

\section{The place and the period of the study}

The research was carried out between August and October 2012. The data were collected at the Clinical School of Physiotherapy Dr. Aderban Martins de Medeiros, from Faculdades Integradas de Patos - PB, at night shifts and on alternate days.

\section{Population, sampling and sample}

The population was composed of 388 students from the Physiotherapy Course of Faculdades Integradas de Patos - FIP. The sampling was by convenience and not probabilistic making up to 26 subjects, both genders. The subjects were randomly assigned to 2 groups, making up to a total of 13 individuals in each group. Group 1 or experimental (G1) group was submitted to MET. Group 2 (G2) or the control group was submitted to self- stretching.

\section{Inclusion and exclusion criteria}

Orthopedic and cardiovascular alterations which would constrain the achievement of the proposed exercises or offer them risk. It was necessary condition for participation in the research, the consent of the subjects agreed by signing the free and informed consent of the research.

It was excluded the subjects who were absent one assessment or to an intervention (be MET, be self-stretching) during the intervention period and/ or evaluations, started the practice of physical activity during the data collection period, presented muscle contracture or muscle stretching in less than 60 days before the beginning of the program, had cardiac pathology not controlled and practiced activities such as Pilates, yoga or alike.

\section{Collection procedures}

The collected data followed the following steps:

1. Filling up of an identification sheet (name, age, gender, group to which he or she is part of, body mass and stature self-referred);

2. Flexibility assessment of posterior master chain;

3. Performing of MET (G1) and self-stretching (G2);

4. Flexibility reassessment.

\section{Flexibility assessment of posterior master chain}

To assess the flexibility of the master posterior chain of the subjects it was used the sit-and-reach test.

The instrument adopted for measuring the flexibility was the test bank Wells.The flexibility of the participants was measured on a scale in centimeters, present in the database, during the execution of the test.

When performing the test, the evaluated subject was barefoot, sitting with the extended knees, lower limbs slightly separated, feet firmly on the test bank Wells, elbows and upper limbs flexed previously. From this position, the performer was conducting a forward movement with the trunk, trying to achieve with the finger tips the largest displacement possible on a graduated scale in centimeters located on the upper part of the seat.

To ensure the validity of the measurements obtained, the evaluator has maintained the knees 
of the participant in a neutral position under firm manual pressure and observed if the hands were symmetrically overlaying during the execution of the test, to avoid errors in measurement. In addition, the evaluated subject remained at the final position reached for at least two seconds so that there was a better definition of the measurement obtained.

\section{Performing of MET (G1) and self-stretching (G2)}

Each subject of $\mathrm{G} 1$ underwent 10 attendances with MET. The attendances occurred in non-consecutive days, at night, in acclimatized room, endowed with stretchers where the patients were comfortably positioned for the execution of the technique. Each attendance, from the first to the tenth, the steps listed below were followed:

1. The application MET to spinal erectors, for 5 cycles of stretching followed by isometric contraction. Each cycle started with an isometric contraction maintained for 10 seconds, in intensity from 20 to $25 \%$ of maximum contraction, contrary to the strength of the therapist, followed by slow and gradual passive stretching of the muscle previously contracted until theelastic barrier presented by the muscle tendinous unit. After this, new cycle was initiated.

2. The application of MET bilaterally to hip extensors in a similar way to the previous group.

3. The application of MET bilaterally to pelvitrocanterians in a similar way to the previous group.

4. The application of MET bilaterally to hamstrings in a similar way to the previous group.

5. The application of MET bilaterally to gastrocnemius in a similar way to the previous group.

6. The application of MET bilaterally to soleus in a similar way to the previous group.

7. The application of MET bilaterally to sole of the foot in a similar way to the previous group.

For the control group (G2), each subject was submitted to 10 attendances for the realization of self-stretching. The attendances occurred in nonconsecutive days, at night, in acclimatized room, endowed with stretchers where the patients were comfortably positioned for the execution of the technique. Each attendance, from the first to the tenth, the steps listed below were followed:

1. Implementation of self-stretching for triceps sure and sole of the foot, bilaterally, with the maintenance of the position of stretching over a period of 30 seconds.

2. Implementation of self-stretching for hamstrings, bilaterally, with maintenance of the position of stretching over a period of 30 seconds.

3. Performing of self-stretching to the gluteus maximus, bilaterally with the maintenance position of stretching for a period of 30 seconds.

4. Performing of self-stretching for pelvitrocanterians, bilaterally with the maintenance costs of the position of stretching for a period of 30 seconds.

5. Performing of self-stretching to the spinal erectors, bilaterally with the maintenance costs of the position of stretching for a period of 30 seconds.

\section{Flexibility assessment of posterior master chain}

Immediately after the end of the last attendance, each subject of both groups was reassessed by following the same procedures adopted initially on measurement of the flexibility of master posterior chain.

\section{Data analysis}

As support for the statistical treatment and formation of database it was used the Statistical Package for the social Sciences (SPSS) 18.0 for Windows. The Student t test, with significance level of $p<$ 0.05 was used to evaluate whether there was any significant difference between the averages of two groups of techniques, MET and self-stretching. After this statistical monitoring of the data, the same were arranged in the form of tables and graphs 
by the programs Microsoft Word and Excel version 2010.

\section{Ethical Aspects}

The study followed the ethical and legal aspects of Resolution 196/96 of the NationalCouncilof Health on research involving human beings [15].

\section{Results}

The sample of this study was formed by 26 university students of the Physical Therapy Course of Faculdades Integradas de Patos, divided into two distinct groups, each of them composed by 13 individuals. In group 1 (G1), 2 subjects were male and 11 were female, with the same distribution in group 2 (G2).

The age of the participants in the $\mathrm{G} 1$ ranged between 18 and 23 years and the mean age was 20 years ( $S D=1.30)$, and in $\mathrm{G} 2$ participants' age ranged between 18 and 24 years, with a mean age of 20.3 years $(S D=1.59)$.

The mean body mass of the participants in the $\mathrm{G} 1$ was $58 \mathrm{Kg}(\mathrm{SD}=7.61)$, the mean stature was $1.63 \mathrm{~m}(\mathrm{SD}=0.05)$, and the mean Body Mass Index (BMI) was $21.6 \mathrm{Kg} / \mathrm{m}^{2}(\mathrm{SD}=1.68)$. In group 2 (G2), the mean body mass of participants was $66 \mathrm{~kg}$ $(S D=11.4)$, the mean height was $1.65 \mathrm{~m}(\mathrm{DP}=0.05)$, and the mean $\mathrm{BMI}$ was $23.8 \mathrm{Kg} / \mathrm{m}^{2}$ (SD=3.03).

The average flexibility of participants measured before the application of Muscle Energy Technique was $20.4 \mathrm{~cm}$ (SD=8.37), while the average flexibility obtained after the tenth attendance was $33.6 \mathrm{~cm}$ $(\mathrm{SD}=5.42)$.

Analyzing the mean flexibility before and after the MET application, it was noticed a flexibility gain statistically significant after 10 (ten) attendances ( $p$ $<0.05$ ).

The average flexibility of the participants measured before the application of Muscle Energy Technique was $20.3 \mathrm{~cm}$ (SD=7.52), while the average flexibility obtained after the tenth attendance was $32.7 \mathrm{~cm}(\mathrm{SD}=8.28)$. Analyzing the mean flexibility
Table 1. Differences between the flexibility means (cm) before and after the muscle energy techniques and self-stretching-1.

\begin{tabular}{|c|c|c|c|}
\hline \multicolumn{1}{|c|}{ Groups } & Before & After & t \\
\hline Muscle Energy Techique (G1) & 20.42 & $33.69 *$ & 7.81 \\
\hline Self-Stretching (G2) & 20.38 & 32.73 & 6.91 \\
\hline \multicolumn{2}{|c|}{ Source: Author's data (2012). *: $p=0.038(p<0.05)$} \\
\hline
\end{tabular}

Table 2. Flexibility classification of the posterior chain according to wells and dillon.

\begin{tabular}{|c|c|c|c|c|c|}
\hline Age & Weak & Regular & Medium & Good & Great \\
\hline$<20$ & $<24.5$ & $25-30$ & $31-35$ & $36-39.5$ & $>40$ \\
\hline $20-29$ & $<25$ & $26-30$ & $31-34$ & $35-38$ & $>39$ \\
\hline $30-39$ & $<24$ & $25-28$ & $29-33.5$ & $34-38.5$ & $>39$ \\
\hline $40-49$ & $<22.5$ & $22.5-28$ & $29-32.5$ & $33-37.5$ & $>38$ \\
\hline $50-59$ & $<21.5$ & $22-27$ & $28-32.5$ & $33-37.5$ & $>38$ \\
\hline$>59$ & $<21.5$ & $22-26.5$ & $26.5-31$ & $31-32.5$ & $>33$ \\
\hline & & \multicolumn{5}{c}{ Source: Wells \& Dillon (1952). } \\
\hline & \multicolumn{5}{c}{} \\
\hline
\end{tabular}

before and after the application of the MET, it was noticed a flexibility gain statistically significantafter 10 (ten) attendances ( $p<0.05)$.

The analysis of Table 1 shows the mean values of flexibility of each group of the first attendances and after the last attendance. The group submitted to MET presented an average gain of flexibility of 13.3 $\mathrm{cm}(\mathrm{SD}=5.4)$, while the control group submitted to the technique of self-stretching showed a gain of $12.4 \mathrm{~cm}(\mathrm{SD}=4.48)$. The difference between the averages of flexibility before and after the application of the techniques, showed that MET presents greater effectiveness, statistically significant, in flexibility gain of the posterior master chain ( $p=0.038$ ).

Through the classification proposed by Wells and Dillon (1952), the subject evaluated by the test sitand-reach can have 5 different flexibility categories of flexibility of master posterior chain, as shown in Table 2. The category of flexibility, measured in centimeters, have defined limits that vary according to age into "weak", "regular",medium", "good" and "great". 
In accordance with the values set in Table 2, for the average age from $\mathrm{G} 1$ to 20 years $(D P=1.30)$, the average flexibility of $20.4 \mathrm{~cm}(S D=8.37)$ obtained was initially classified in the category "weak". After the MET application, the final average has reached $33.6 \mathrm{~cm}(S D=5.42)$ category "medium". With respect to individual flexibility gains, it was observed that $92 \%(n=12)$ of the participants in the $\mathrm{G} 1$ showed a gain of Flexibility enough to improve at least one category of flexibility.

In G2, the mean age of participants was 20.3 years $(S D=1.59)$, and the sample before the use of the self-stretching presented initial mean of $20.3 \mathrm{~cm}(S D=7.52)$ and final average of $32.7 \mathrm{~cm}$ $(S D=8.28)$, showing that there was a step forward in the average flexibility, from "weak" to the category "medium". Verifying individually the gains of flexibility, it was observed that $92 \%(n=12)$ of the participants in the $\mathrm{G} 2$ improved the flexibility to the extent of achieving at least a higher category.

\section{Discussion}

One of the main variables of physical fitness related to health is the flexibility, which can be defined as the maximum passive physiological amplitude of a joint. movement, and even from individual to individual and even in the same individual. Basically the flexibility is a result of the ability of elasticity demonstrated by muscles and the tissues of the connectives, combined to the joints mobility [16].

The increase in flexibility is due to the remodeling of the connective tissues, muscles (endomysium and perimysium and epimysium) and semitendinosus, where changes in the length of the tissues may be quantitative and organizational. These modifications are accompanied by adjustments in the myo-contractile proteins of the sarcomeres cytoskeleton. The result of these changes leads to airway remodeling of the muscle tendinous units, which are accompanied by the increase of exten- sibility, in length and resistance to passive dynamic movement [17].

Despite of many studies addressing the theme, there is not consensus yet on the best combination of a single cycle and the number of repetitions of the stretching. To obtain better and more sustainable gains we need a daily stretching program. The duration of the stretching needs to be placed in the context of other parameters such as intensity, frequency and mode of stretching [1].

The results of this study showed MET even without association with other techniques to be more effective than the self-stretching to the gain of muscular flexibility. The study of Alcântara et al (2010), shows that the stretching associated with the proprioceptive neuro muscle facilitation was the technique that presented greater flexibility compared toMuscle Energy Technique [18].

The results of the study of Costa et al. (2009), corroborate the findings of the current study, which shows that the technique of Muscle Energy is more effective in the flexibility gain than static stretching [19].

The results indicated in this study are corroborated by Dahmer (2010), whose study observed that the stretching, both performed in soil, as performed in liquid environment, improved the muscle flexibility sufficiently to the extent of all individuals move to a category of superior flexibility [20].

\section{Conclusion}

The present study was shown to be of great scientific relevance, once that came to contribute for the extension of scientific evidences, as it covered a technique often used in clinical practice, the self-stretching, and a technique that is often little used or even unknown by many professionals of the health area, the muscle energytechnique, whose efficacy for flexibility gain is scientifically proven.

The limitations presented in this study were the number little expressive of the sample, which limits 
generalized conclusions, and the observation of the acute effect of exclusive two techniques on flexibility.

According to the results obtained, it was observed that the muscle energy technique, as well as the self-stretching technique proved to be efficient for the gain of flexibility of the posterior master chain, being MET the one that pointed out better effectiveness.

Facing the limitations of this study, it is realized the importance of new studieswith more robust samples and analyzing the delayed effects of these and other techniques forflexibility gain for which they serve to construct scientific evidence about the theme.

\section{References}

1. Kisner, C; Colby, L. Exercícios Terapêuticos - Fundamentos e Técnicas. São Paulo: Manole, 2009.

2. Rebelatto, J. R.; Calvo, J. I,; Orejuela, J. R.; Portillo, J. C. influência de um programa de atividade física de longa duração sobre a força muscular manual e a flexibilidade corporal de mulheres idosas. Rev. bras. fisioter. Vol. 10, No. 1 (2006), 127-132.

3. Prentice, W. E; Voight, M. L. Técnicas em reabilitação musculoesqueléticas. Porto Alegre: Artmed, 2003.

4. Watkins, J. Estrutura e Função do Sistema Músculo Esquelético. Porto Alegre: Artmed. 2001.

5. Almeida, T. T.; Jabur, N. M. Mitos e verdades sobre flexibilidade: reflexões sobre o treinamento de flexibilidade na saúde dos seres humanos. Motricidade 3 (1): 337-344

6. Alter, M. J. Ciência da Flexibilidade. Porto Alegre: Artmed, 1999.

7. Moffat, M; Vickery, S. Manual de Manutenção e Reeducação Postural. São Paulo: Artmed, 2002

8. Salvador, D.; Neto, P. E. D.; Ferrari, F. P. Aplicação de técnica de energia muscular em coletores de lixo com lombalgia mecânica aguda. Fisioterapia e Pesquisa 12 (2): 20-7, 2005. 9 Campos, G.;

9. Loza, E. Técnicas de energia muscular: princípios e aplicações. Physiothe- rapy; 10 (8): 21 -9, 2001.

10. Chaitow, L. Técnicas de Energia Muscular. São Paulo: Manole, 2001

11. Kendall, F.P; McCreary, E.K; Provance, P.G. Músculos - Provas e Funções com Postura e Dor. São Paulo: Editora Manole LTDA, 2009

12. Souchard, P. Fundamentos da REEDUCAÇÃO POSTURAL GLOBAL: Princípios e Originalidade. São Paulo: É Realizações, 2009.
13. Pereira, M. G; Epidemiologia - Teoria e Prática. Rio de Janeiro: Guanabara Koogan, 2008.

14. Cozby, P C.Métodos de pesquisa em ciências do comportamento. São Paulo: Atlas, 2003

15. Brasil. Ministério da saúde. Conselho Nacional de saúde. Resolução 466/12. Brasília- DF, 2012.

16. Melo, L. M. O.; Silva, M. T.; Costa, I. T.; Pires, F. O.; Campos, C. E. Relação da flexibilidade na velocidade de corrida de jogadores de futebol. Rev Bras Futebol 2009 Jan-Jun; 02 (1): 36-44.

17. Prado, L. G.; Makarenko, I.; Andresen, C.; Kruger, M.; Opitz, C. A.; Linke, W. A. Isoform diversity of giant proteins in relation to passive and active contractile properties of rabbit ske- letal muscles. J Gen Physiol, 2005.

18. Alcântara, M. A.; Firmino, F. R.; Lage, R. F. Efeitos agudos do alongamento: uma comparação entre as técnicas de facilitação neuromuscular proprioceptiva e energia muscular. $R$. bras. Ci. e Mov, 2010

19. Costa, M. A. M.; Ferreira, J. I. A.; Almeida, A.; Mendonça, R.; Fortes, R.; Escobar, R. Análise comparativa da eficácia do alongamento manual entre a técnica de energia muscular e o alongamento estático. Fisioterapia Brasil, 2009.

20. Dahmer, M. R. Estudo comparativo sobre programas de alongamento estático em solo e no meio líquido em atletas de uma equipe de voleibol feminino do vale do Taquari-RS. 2010.

\section{Publish in International Archives of Medicine}

International Archives of Medicine is an open access journal publishing articles encompassing all aspects of medical science and clinical practice. IAM is considered a megajournal with independent sections on all areas of medicine. IAM is a really international journal with authors and board members from all around the world. The journal is widely indexed and classified Q1 in category Medicine. 